\title{
New rules or old concepts? The golden jackal (Canis aureus) and its legal status in Central Europe
}

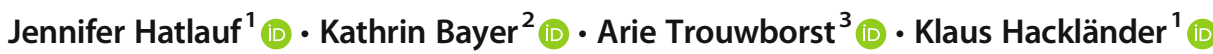

Received: 9 April 2020 / Revised: 11 October 2020 / Accepted: 26 December 2020 / Published online: 18 February 2021

(C) The Author(s) 2021

\begin{abstract}
Conflicts have emerged due to range expansions of the golden jackal (Canis aureus) across Europe, characterized by their international conservation status and perceived impacts on livestock and native prey species. Most countries in Central Europe do not yet include the golden jackal in their national list of occurring, native species. Nevertheless, legal obligations arise as soon as golden jackals colonize a particular country. Legal implications of this range expansion were described in past studies from an international perspective. However, they left out specifics on the legal status within any particular country. Therefore, we examine the actual legal status within Central European countries, exemplifying the diverse federal and provincial laws. In particular, we assess the current conservation and hunting laws in Austria's provinces and discuss them in the context of neighbouring countries to analyse implications for relevant authorities. We found substantial contrasts not only among provinces but also between direct neighbouring countries, impeding efforts for transboundary species conservation and leading to complications regarding the management of this species. Improved procedures for collecting records and hunting-bag data appear necessary for future species assessment on a European level and management on a local level. We recommend a more unified legal system but adjusted to actual golden jackal presence on the regional and cross-border level, combined assessment, or similar management strategies to minimize conflicts, reduce persecution, and clarify legal obligations.
\end{abstract}

Keywords Golden jackal $\cdot$ Bern Convention $\cdot$ Habitats Directive $\cdot$ Inconsistent legislation $\cdot$ Conservation $\cdot$ Hunting law

\section{Introduction}

The golden jackal (Canis aureus moreoticus Geoffroy Saint-Hilaire 1835) has been expanding its natural range across large parts of Europe for many years (Arnold et al. 2012; Trouwborst et al. 2015; Krofel et al. 2017). Whereas palaeontological data regarding the first appearance of golden jackals on this continent remain controversial (Spassov and Acosta-Pankov 2019), the first verified golden jackal records date from around the year 1384 in Southeastern

Jennifer Hatlauf

jennifer.hatlauf@boku.ac.at

1 Department of Integrative Biology and Biodiversity Research, Institute of Wildlife Biology and Game Management, University of Natural Resources and Life Sciences (BOKU), Vienna, Austria

2 Law Firm Eisenberger Rechtsanwälte GmbH, Vienna/Graz, Austria

3 Department of Public Law and Governance, Tilburg Law School, Tilburg University, Tilburg, The Netherlands
Europe, near Sofia (Bulgaria) (Georgiev 1983 in Spassov 1989). In the 1800s, there are references to the golden jackal in Hungary, the species being referred to as 'reed wolf' (Tóth et al. 2009). Some individuals may have dispersed from Hungary to Austria, but the evidence is not clear (Hoi-Leitner and Kraus 1989). So far, golden jackals have been reported in 33 European countries. In 10 of these, golden jackals were recorded for the first time in the past 10 years: Switzerland (2011, KORA 2012), Estonia and Latvia (2013, Männil et al. 2014; Veeroja and Männil 2018), Poland (2015, Kowalczyk et al. 2015), Denmark (2015, Trolle 2015), Lithuania (2015, Paulauskas et al. 2018), The Netherlands (2016, van der Grift 2016), France (2017; Bouchet 2017), Liechtenstein (2018; Landesverwaltung Fürstentum Liechtenstein 2018), and Finland (2019; Koistinen 2019).

Whether the expansion of golden jackals in Europe is seen as natural or not, as positive or negative, the arrival of the species in the aforementioned countries is a fact. This development can generate various policy-relevant issues for wildlife conservation and management authorities. There has been 
DNA-based evidence for golden jackal attacks on sheep in Germany (Ministerium für Energiewende, Landwirtschaft, Umwelt, Natur und Digitalisierung 2017) and Denmark (Anonymous 2017). Predation on sheep was also recorded (without DNA analysis) in Italy (Fanin et al. 2018), although attacks ceased immediately after protective fences were installed (Fanin, personal communication). Evidence of livestock kills or expected ecological effects can generate negative perceptions about the species (Heltai et al. 2013; Maran 2015; Levickaite 2015; Dios et al. 2018). There has been no scientific evidence of negative ecological impact. However, studies across Europe show that golden jackals are generalist and opportunistic omnivorous animals whose diet overlaps strongly with that of red foxes (Vulpes vulpes) in most areas (Lanszki et al. 2016; Ćirović et al. 2014), thus indicating possible competition between the two species (Farkas et al. 2017). Whether decreases in hunting bags for deer species (e.g. fallow deer, Dama dama) in Hungary (especially in the southern part) are related to increasing numbers of golden jackals remains under discussion (Hatlauf et al. 2018a; Wallendums 2019). Declines in certain prey populations are better explained by diverse drivers including habitat destruction, degradation, and fragmentation as well as diseases, invasive alien species or interspecific competition, or by limiting factors, such as severe winters (Graham et al. 2005; Sinclair et al. 2012). Policy-making regarding wildlife management is sometimes driven by public perception more than scientific evidence (Head 2016). In the case of golden jackals, their evidence-based flexible and generalist diet strongly contrasts with the perceived impact (e.g. shown in Hessenberger 2017) on presumed prey species; however, it is sometimes these perceptions combined with observed changes in golden jackal populations that induce policy changes (Levickaite 2015; European Commission 2016). Moreover, the aforementioned reports of livestock depredations and complaints to authorities have raised, a.o., the following policy-relevant questions in countries recently colonized by golden jackals: Is the culling of golden jackals possible within the applicable legislation, and what are the most efficient methods? Should the golden jackal be listed as a game species, a protected species, or as neither of those? Should it be hunted year-round or only during a specific hunting season? Will there be damage to livestock? How can potential damage be proven? Should there be damage mitigation and/or compensation for losses in animal husbandry? How can livestock be protected from golden jackals? Is golden jackal monitoring necessary? Does a clear legal framework, combined with damage mitigation and compensation schemes, contribute to a better human-predator coexistence? The answers to these questions might not be clearcut and are influenced by international wildlife conservation legislation. The lack of legal clarity was evident, for example, in Lithuania, where the golden jackal was first classified as an invasive alien species; however, this status was later removed
(Levickaite 2015; Stratford 2015; European Commission 2016).

Implications of the aforementioned range expansion have previously been discussed from a pan-European wildlife management and legal perspective. Applicability of international instruments and implications for the status of the species (i.e. game, protected, or no status) in Europe was analysed in previous studies (Trouwborst et al. 2015; Somsen and Trouwborst 2019). However, the problems relating to the legal status of the species within a federal state have never been discussed. To help fill this gap, we examine the legal status of golden jackals in Austria in depth and relate it to the broader context of other Central European countries-Germany, Czech Republic, Poland, Slovakia, Hungary, Slovenia, Italy, Switzerland, and Liechtenstein. Austria has a strongly decentralized governance structure. It has nine provinces (Fig. 1), which are not only administrative units, but actually hold legislative authority, distinct from the federal government, for a number of issues including nature protection and hunting. The situation of Austria is of particular interest for various reasons. Firstly, it is situated between countries with well-established golden jackal populations in Southeastern Europe and countries with sporadic occurrence of the species in the north and northwest (see map in Krofel et al. 2017), with a cluster of reproductive golden jackal groups in Estonia (Veeroja and Männil 2018), one reported reproduction in the Czech Republic (Jirků et al. 2018) and most recently a first reproduction in Poland (Kowalczyk et al. 2020). Therefore, we expect a great diversity of legal regulations among the countries along this north-south gradient in terms of golden jackal occurrence. Secondly, the first confirmed golden jackal appeared in Austria relatively recently, in 1987 (Hoi-Leitner and Kraus 1989), and the first reproductive group was found only 20 years later, in 2007 (Herzig-Straschil 2008); further groups were confirmed in 2016 (Hatlauf et al. 2017).

Our paper has three main objectives. Firstly, we provide an in-depth analysis of the diverse federal and provincial conservation and hunting laws in relation to the golden jackal in Austria. We examine the legal status that each province currently assigns to the golden jackal. Secondly, we assess the implications of the distribution of golden jackals against the backdrop of records in each province and of the heterogeneous legislation of the neighbouring countries with a view of possible future transnational management and/or conservation efforts. Thirdly, we briefly examine the legislation concerning golden jackals in central Europe in relation to their colonization status. Furthermore, we identify the most relevant obligations under current international and European legal instruments which pertain to the management and conservation of the golden jackal, in particular the Convention on Biological Diversity (CBD 1992), the Convention on the Conservation of European Wildlife and Natural Habitats (the Bern Convention Council of Europe 


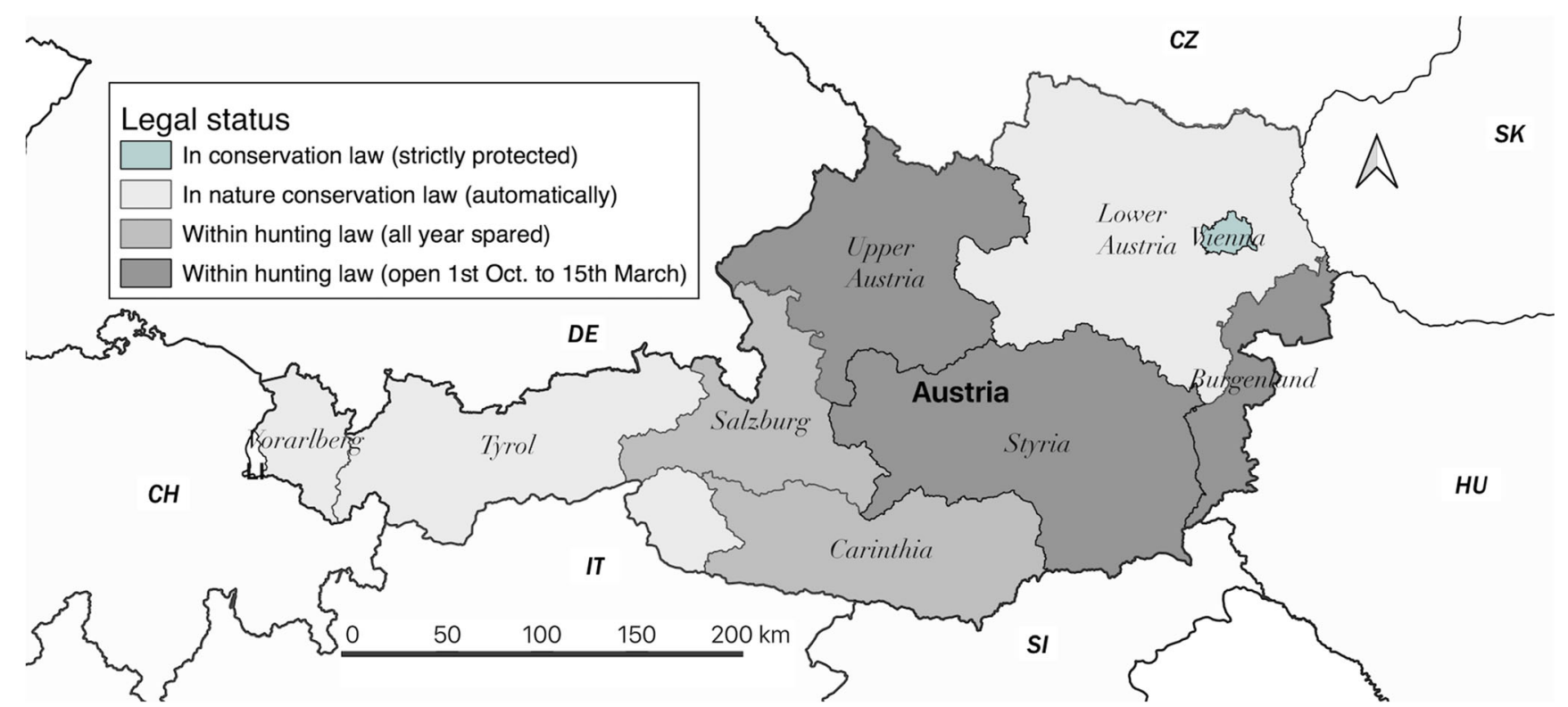

Fig. 1 Legal status of the golden jackal in Austria's provinces. Handled within the hunting law with an open season (dark grey); treated within the hunting law but all year protected, therefore non huntable (mid-grey);

either automatically part of the nature conservation acts (light grey) or specifically mentioned as strictly protected, like in Vienna (white with grey point) (Status 2020)

1979), and Directive 92/43/EEC on the Conservation of Natural Habitats and of Wild Fauna and Flora (EU Habitats Directive 1992). We also assess to what extent the concept of 'Raubzeug', which is comparable to an expression like 'vermin', is sometimes being applied to golden jackals in one of Austrian's province (e.g. see Thöne 2012). Lastly, we contextualize the results regarding current golden jackal distribution and analyse whether the provinces meet their legal obligations under the $\mathrm{CBD}$, the Bern Convention, and the Habitats Directive. We use an integrated approach of linking a literature review with the analysis of legislation and golden jackal distribution in Austria, combined with a review of secondary sources for neighbouring countries. We aim at presenting an overview of existing laws, clarifying applicable legal obligations, and exemplifying the diversity of rules within a federal country with more than one administrative unit.

The colonization of Austria by the golden jackal and its handling by the Austrian authorities at both federal and provincial levels can therefore serve as an example - positive or negative - for other countries that will be in a similar situation in the future, with a view of possible transboundary cooperation.

\section{Methods}

\section{Confirmed golden jackal presence}

We summarized the confirmed golden jackal records in Austria by reviewing the literature between 1987 and 2018 .
We only included records based on publications of documented hard facts (category 'C1' based on the SCALP (Status and Conservation of the Alpine Lynx Population) criteria (Molinari-Jobin et al. 2003), adapted for golden jackals by Hatlauf et al. (2016b). Confirmed golden jackal records for Austria had been reported by Hoi-Leitner and Kraus (1989), Zedrosser (1995), Bauer and Suchentrunk (1995), Humer (2006), Plass (2007), Herzig-Straschil (2008), Hatlauf and Hackländer (2016a; b), and Hatlauf et al. (2017).

\section{Legal analysis}

For the legal analysis, we firstly examined which international and national instruments apply specifically to the golden jackal. Secondly, we interpreted definitions and terms from these instruments and assessed their implications for policymaking.

When interpreting international legal instruments, we used the standard rules of treaty interpretation as codified in the 1969 Vienna Convention on the Law of Treaties. As such, we considered the binding text of their provisions, in their context and in light of the instruments' overarching objectives, and subsequently the accompanying documentation (including guidance documents of the European Commission), as well as case law and legal literature.

We interpreted national legislation on the grounds of $\S 6$ of the Austrian Civil Code according to the following attributes: wording, context, teleology, and genesis. We also looked at corresponding case law and legal literature dogmatically. 
Table 1 International and national legal instruments (italic: instruments that were analysed in view of the golden jackal for Austria)

\begin{tabular}{ll}
\hline Legal instruments & Level \\
\hline CITES - The Convention on International Trade in Endangered Species of Wild Fauna and & International \\
Flora of 3 March 1973 & \\
CMS - The Bonn Convention on the Conservation of Migratory Species of Wild Animals of 23 & International \\
June 1979 & \\
CBD - Convention on Biological Diversity of 5 June 1992 & International \\
Bern Convention - on the Conservation of European Wildlife and Natural Habitats of 19 & International \\
October 1979 & International \\
EU Habitats Directive - the Council Directive 92/43/EEC of 21 May 1992 on the conservation & \\
of natural habitats and of wild fauna and flora & International \\
EU IAS Regulation - No 1143/2014 of the European Parliament and of the Council of 22 & \\
October 2014 on the prevention and management of the introduction and spread of invasive & \\
alien species & National \\
Animal Welfare Act & Provincial \\
Conservation Acts & Provincial \\
Hunting Laws &
\end{tabular}

\section{Results}

\section{Golden jackal records}

First occurrences of golden jackals in Austria's provinces showed 11 records between 1987 and 1995 (documented in Hoi-Leitner and Kraus 1989; Bauer and Suchentrunk 1995; Zedrosser 1995). This is reflecting the state of data at the time of Austria joining the EU (on 1 January 1995) and therefore from this point forward falling under the EU Habitats Directive. Up until 2007, there were a total of 17 observations of single and presumed vagrant golden jackals (Plass 2007; Humer 2006). In 2007 first reproduction was then observed in the Lake Neusiedl-Seewinkel National Park (Herzig-Straschil 2008). From 2007 to 2017, a minimum of 40 single records (roadkills, camera trap pictures, or accidentally shot individuals) indicated sporadic presence of vagrant individuals on the search for mating partners and territories in the provinces Burgenland, Lower Austria, Styria, Carinthia, and Upper Austria (Hatlauf et al. 2017; and unpublished data). Additionally, actively collected data through bioacoustic surveys officially confirmed the second reproduction in 2016 (Hatlauf and Hackländer 2016a), and both pictures and surveys reconfirmed reproduction and a minimum of three to four more groups in the following season $(2016 / 2017)^{1}$ (Hatlauf and Hackländer 2016a, 2016b; Hatlauf et al. 2017).

\section{Legal instruments on the conservation of the golden jackal: international law}

There are several legal instruments that are at least potentially relevant to the golden jackal (Table 1). On an international level CITES (1973), the CMS (1979) and the CBD (1992)

\footnotetext{
${ }^{1}$ Summary of more collected data will be available: www.goldschakal.at
}

cover certain large carnivores. The broad scope of the CBD, which covers all biodiversity, also encompasses golden jackals. CITES and the CMS currently do not apply to golden jackals in Europe, however (CITES only lists the species for India, and the species is not listed at all under the CMS). The golden jackal is not covered by the IAS Regulation (2014) either, as it is not included in the 'list of invasive alien species of Union concern' (European Union 2017) and, moreover, is not considered an alien species in the first place (European Commission 2016; Trouwborst et al. 2015; Somsen and Trouwborst 2019). As discussed below in further detail, the $\mathrm{CBD}$, the Bern Convention, and the EU Habitats Directive are indeed of relevance to golden jackals in Austria.

\section{Convention on Biological Diversity}

According to its Article 1, the CBD has three objectives: (1) the conservation of biological diversity, including diversity within species and between species, (2) the sustainable use of its components, and (3) the fair and equitable sharing of the benefits arising out of the utilization of genetic resources.

Inter alia, the Convention commits its parties, including Austria, to the taking of various in situ measures (Harrop 2011). Based on Article 8 par. a and b of the CBD, Austria shall, 'as far as possible and as appropriate', establish a system of protected areas and regulate the use of biological resources vital for the conservation of biological diversity within and outside of protected areas. Under Article 8 par. $f$ and $\mathrm{k}$ of the $\mathrm{CBD}$, Austria is also obliged to promote the recovery of threatened species, for example, by implementing plans or management strategies, and to either develop or maintain necessary legislation as well as regulatory provisions for the protection of threatened species and populations. In situ measures should conserve ecosystems and natural habitats 
and maintain or recover viable populations in their natural surroundings.

\section{Bern Convention}

The Bern Convention aims to conserve all (European) wild flora and fauna and their natural habitats, especially those species and habitats whose conservation requires the cooperation of several countries, and to promote such cooperation (Article 1). The focus lies on endangered and vulnerable (including migratory) species that are listed in Appendices I to III. Appendix IV lists prohibited means and methods of killing, capture, and other forms of exploitation.

The golden jackal is not listed in Appendix II or III. Therefore, only general conservation obligations are applicable. The principal of these obligations follows from Article 2, which requires parties, including Austria, to 'take requisite measures to maintain the population of wild flora and fauna at, or adapt it to, a level which corresponds in particular to ecological, scientific and cultural requirements, while taking account of economic and recreational requirements and the sub-species, varieties or forms at risk locally'. This obligation applies to all wildlife, including the golden jackal. What the 'level' referred to in Article 2 should amount to in concrete instances would appear to depend in part on the circumstances involved and on the opinion of the party concerned. However, as discussed in more detail elsewhere, it does appear safe to assume that species should at a minimum be conserved with a view to avoiding their becoming threatened in terms of national or international Red Lists (Bowman et al. 2010; Trouwborst et al. 2017a). Similarly, Article 2's formulation apparently suggests that conservation considerations should take precedence over socio-economic considerations in cases of irreconcilable conflict between the two (Bowman et al. 2010; Trouwborst et al. 2017a).

\section{EU Habitats Directive}

The EU Habitats Directive aims to safeguard biodiversity by conserving natural habitats and wild fauna and flora while considering economic, social, cultural, and regional needs. The main focus of this Directive is maintaining or restoring natural habitats and animal species. Under Article 14 of the Directive, Member States shall ensure that the exploitation and taking of wild animals listed in Annex $\mathrm{V}$ is compatible with maintaining them in a favourable conservation status (FCS). Furthermore, under Article 15, Member States shall prohibit certain means of capture and killing of animals belonging to Annex V species. Exceptions (derogations) are possible to this prohibition of Article 15 if three conditions are met, enumerated in Article 16. First, the exception must be for one of the purposes mentioned in Article 16. These include research, reintroduction, prevention of serious damage to livestock, public health, and 'imperative reasons of overriding public interest'. Second, the exception can only be allowed if it is proven that the purpose involved cannot be achieved in another way. Third, the exception may not jeopardize the achievement or maintenance of a FCS.

As a Member State of the EU (since 1995), Austria must comply with the Habitats Directive, which is legally binding and directly enforceable in national courts (Evans et al. 2013). Under the Habitats Directive, the golden jackal is a 'species of Community interest', listed in Annex V. A species of Community interest is defined as a species occurring within the European territory of the Member States, which is either (i) endangered, (ii) vulnerable, (iii) rare, or (iv) endemic, and requiring particular attention for reasons of the specific nature of their habitat, the potential impact of their exploitation on their habitat, or their conservation status (Article $1(\mathrm{~g})$ ).

Species of Community interest can not only be listed in Annex $\mathrm{V}$ but also in Annex II or IV, which require designation of protected areas and strict protection, respectively. However, these stricter regimes were not chosen for the golden jackal (Trouwborst et al. 2015). Exploiting or taking golden jackals, therefore, is legally possible when (a) it is ensured they are kept in a FCS, (b) the population is monitored (which is an independent obligation under Article 11, but also necessary to ensure FCS), and (c) the obligation concerning prohibited means and modes of capture and killing is observed. The Habitats Directive defines the conservation status of a species as 'the sum of influences acting on the species concerned that may affect the long-term distribution and abundance of its populations' within the European territory (Article 1(i)).

A conservation status is considered 'favourable' when three cumulative components are met: (i) population dynamics data of the golden jackal indicate that it is maintaining itself on a long-term basis as a viable component of its natural habitats, (ii) the natural range of the golden jackal is neither being reduced nor is likely to be reduced for the foreseeable future, and (iii) there is, and will probably continue to be, a sufficiently large habitat to maintain the golden jackal's populations on a long-term basis (Article 1(i)). The precise meaning of the term FCS remains subject to some confusion and controversy (Epstein et al. 2016; Trouwborst et al. 2017b). Uncertainty remains, for instance, regarding the important question at what level the FCS should be achieved and measured precisely - especially, whether population dynamics data must be obtained and applied for the territory of each Member State, or for the entire EU, or at the level of concrete (transboundary) populations, or otherwise (Epstein et al. 2016; Trouwborst et al. 2017b). In a recent ruling, however, the Court of Justice of the EU provided some further clarity, in a case concerning the hunting of wolves (Canis lupus) in Finland (Case C-674/17, 10 October 2019). Importantly, the Court clarified that there is scope, in principle, to focus on 
conservation status at the level of discrete transboundary populations shared by various EU Member States. According to the ruling, conservation status and the impact of derogations thereon must be assessed both (1) at a local level and (2) on the scale of the territory of the Member State involved, or, in Member States straddling more than one biogeographical region, the scale of the biogeographical region in question within the Member State, or, 'if the natural range of the species so requires and, to the extent possible, at a crossborder level' (Case C-674/17, par. 56). Unfortunately, the Court did not explain under what conditions precisely a transboundary approach is appropriate, including the question whether it is necessary to have in place a transboundary population-level management plan (see Linnell et al. 2008; Trouwborst et al. 2017b). The ruling does clarify that no account may be taken of those parts of a transboundary population which are located in non-EU Member States which are 'not bound by an obligation of strict protection of species of interest for the European Union' (Case C-674/17, par. 60). Regarding the local level, the Court observed that 'the assessment of the impact of a derogation at the level of the territory of a local population is generally necessary in order to determine its impact on the conservation status of the population concerned on a larger scale' (par. 59). In addition, the 'conservation status of a population at national or biogeographical level depends also on the cumulative impact of the various derogations affecting local areas' (par. 59). Moreover, Member State authorities must ensure that the granting of derogations does not jeopardize the 'long-term preservation of the dynamics and social stability of the species in question' (par. 57).

Applying this now to golden jackals and to Austria, it would appear that in order to comply with their obligation to ensure a FCS for the golden jackal, the relevant Austrian authorities must consider both the impact of management measures at local levels and ensure that a FCS is achieved or maintained at a larger scale, which may be (i) the levels of each of the two biogeographical regions within Austria (alpine and continental), and/or perhaps (ii) the national level, and/or perhaps (iii) the level of the transboundary population(s) of which the Austrian golden jackals are a part. Whether, and if so under what conditions, options (ii) and (iii) are legally viable remains unclear, although having a transboundary population-level management plan in place would clearly increase the chances of a transboundary approach standing up in court. It is clear, in any case, that even when assuming that a transboundary approach is appropriate, no account may be taken of golden jackals in Switzerland, Bosnia and Herzegovina, Serbia, Kosovo, Montenegro, Albania, North Macedonia, Moldova, the Ukraine, Turkey, and other third countries beyond the EU. The European Commission has endorsed a transboundary approach with regard to the large carnivore species wolf, brown bear (Ursus arctos), Eurasian lynx
(Lynx lynx), and wolverine (Gulo gulo) (European Commission 2007; Linnell et al. 2008), and the Court has now apparently confirmed that such an approach can indeed, in principle, be appropriate for wolves (Case C-674/17). Although a similar approach might be appropriate for golden jackals, this cannot blindly be assumed. On the one hand, there could well be benefits to the exchange of information and experiences, and the coordination of golden jackal management, across jurisdictional boundaries, whether internal or international. On the other hand, the smaller home ranges and higher densities of golden jackals imply that they are less dependent on transboundary cooperation to achieve population viability, and golden jackals are also less prone to the conflicts that are typically associated with the larger carnivores (Trouwborst et al. 2015).

\section{Legal instruments on the conservation of the golden jackal: national law}

According to Article 11 (1) no. 8 of the Austrian Constitution, animal welfare is regulated by the Federation (to the extent that the Federation is not entitled to legislate a matter according to other provisions). Matters regarding practicing hunting or fishing ('Ausübung der Jagd oder der Fischerei') and matters for nature conservation are explicitly not covered by Article 11 (1) no 8. of the Austrian Constitution, but of Article 15 of the Austrian Constitution (so-called 'general clause towards provinces'), therefore leaving the regulation of hunting and fishing, and nature conservation in the hands of the provinces.

Concerning animal welfare, a nationwide Austrian Animal Welfare Act exists. We therefore summarize the golden jackal's national status in this matter first. Concerning hunting and nature conservation, there is no nationwide hunting act or nature conservation act. We therefore summarize the results for each province (Table 2 and Fig. 1). The provinces (in compliance with superordinate legal instruments) can autonomously regulate which wild animals are defined as huntable game or protected game in the hunting acts and which wild animals are defined as protected in nature conservation acts.

\section{Austrian Animal Welfare Act (national status)}

The Austrian Animal Welfare Act applies to all animals. Specific paragraphs, however, are only applicable to vertebrates, cephalopods and decapods. These paragraphs cover, for example, the prohibition to perform tests on animals or requirements for animal keeping. Killing animals without due reason is prohibited. Furthermore, with only a few exceptions (p.e. for scientific purposes), killing vertebrates may only be carried out by veterinarians. In this context, one exception to the scope of application of the Austrian Animal Welfare Act exists: Due to its $\$ 3(4)$ the 
Table 2 Legal status of the golden jackal in Austria's provinces (Status 2020)

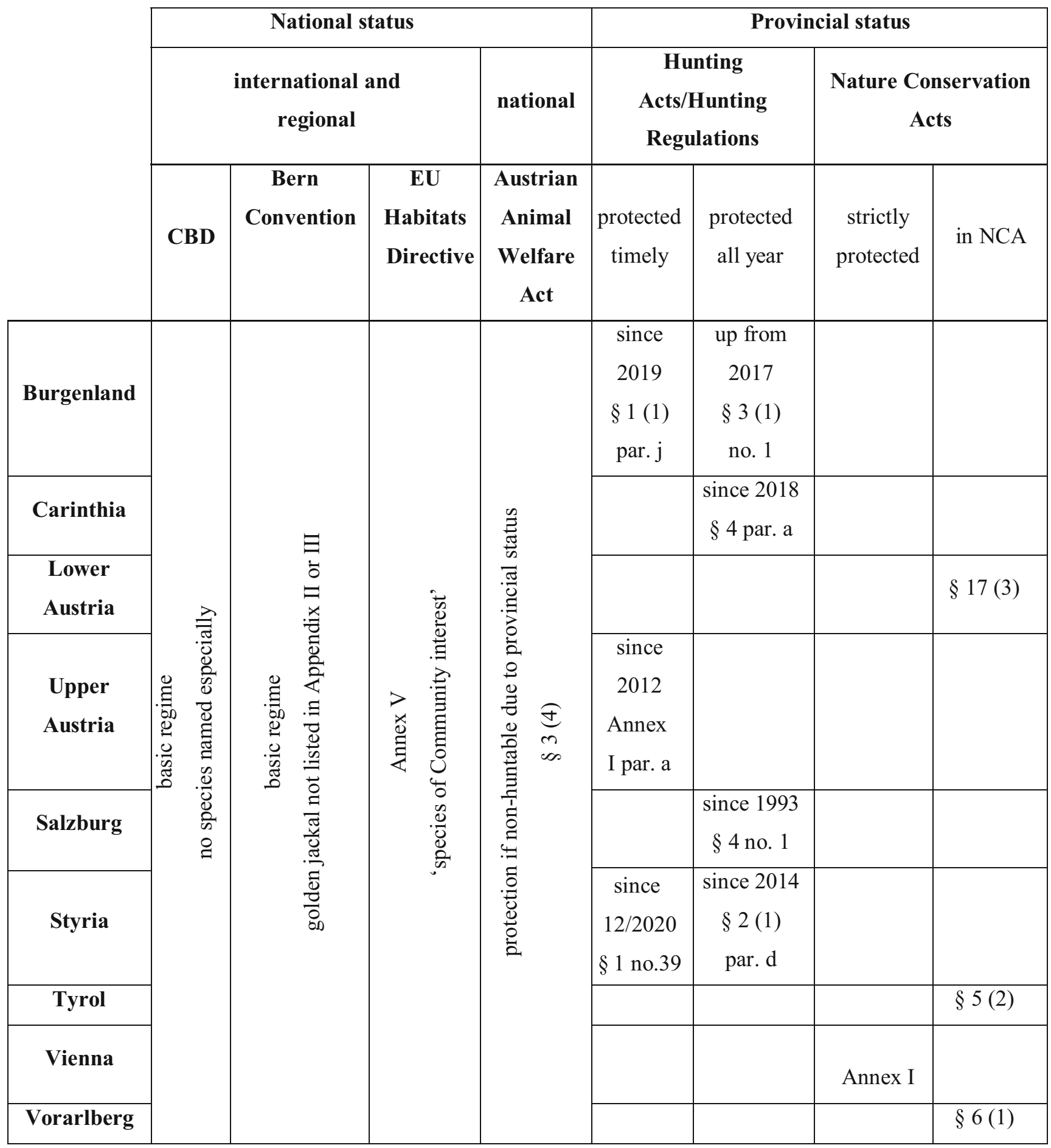

Austrian Animal Welfare Act does not apply to hunting. Thus, practicing hunting within the given limits provided by hunting acts of the provinces does not fall under the Austrian Animal Welfare Act. Practicing hunting outside these limits (for example killing wild animals that are not declared to be game by hunting acts of the provinces), however, is not exempted.

\section{Hunting and conservation law: provincial status}

\section{Burgenland}

The Hunting Act of Burgenland mentions the golden jackal since an amendment that entered into force in May $2017(\S 3$ 
(1) no. 1). The golden jackal was not explicitly named in the hunting act before that. And even after May 2017, there was no defined open hunting season for the golden jackal in the Burgenland Regulation on hunting periods. However, $\S 1$ (1) par. $\mathrm{j}$ of the Burgenland Regulation, which entered into force on the 6th November 2019 (Provincial Law Gazette of Burgenland 2019/79) now defines a hunting period for the golden jackal from the 1st of October to the 15th of May, without given minimum or maximum numbers yet. Defining a hunting period in the Burgenland Regulation on hunting periods did not require a separate resolution by the provincial parliament. The provincial government could therefore on its own determine a hunting period for the golden jackal.

\section{Carinthia}

The Carinthian government defined the golden jackal as game in $\S 4$ par. a of the Hunting Act of Carinthia. Initiated by the official Carinthian hunting organization the new amendment entered into force in March 2018. This initiative is based on the opinion that (1) the golden jackal should be considered an invasive alien species - contrary to widely accepted definitions adopted under international legal instruments, according to which the golden jackal is not an invasive alien species (Trouwborst et al. 2015; European Commission 2016) - and (2) at the same time tends to get confused with the fox, and (3) in view of European law obligations is an unwanted and nonnative game species (see preparatory materials relating to the amendment: provincial government bill, October 2017, p. 2 , to $\S 4$ par. a). Thus, the golden jackal has been listed as game. Up to now, however, the Carinthian Regulation on hunting does not set an open hunting season for the golden jackal. As the Carinthian hunting organization is a public body and in charge of this Regulation, the executive board of the Carinthian hunting organization could itself determine hunting periods for the golden jackal.

\section{Lower Austria}

The Hunting Act of Lower Austria does not explicitly mention the golden jackal as game. Neither do other hunting-related laws in this province. As the golden jackal is listed in Annex V of the EU's Habitats Directive, $\S 17$ (3) of the nature conservation Act of Lower Austria is applicable. The golden jackal therefore must not be deliberately disturbed, captured, injured, killed, kept or removed. $\S 64$ (1) of the Hunting Act of Lower Austria is a provision on so-called Raubzeug, which most closely translates as 'vermin' and refers to mammals and bird species that are not included in the nature conservation nor hunting law and that might cause damage to game species. According to this provision, hunters need to take care of game and prevent damage by vermin, such as straying domestic dogs and cats. According to a Lower Austrian hunting association official, the golden jackal is a protected species (Lebersorger 2009). By contrast, according to other documents, the golden jackal is to be handled as vermin in Lower Austria. In particular, these include statements by hunting association representatives (Alois Gansterer in Thöne 2012) and recommendations in hunting warden manuals (Anonymous s.a). The classification as vermin has multiple explanations. For example, one line of reasoning is that the species is neither listed as huntable game nor is it specifically mentioned in the nature conservation. The classification is therefore left open for additional options. Nevertheless, there is no official provision by a regional administration stating that the golden jackal should be classified as vermin, 'Raubzeug'. An official legal classification for golden jackals in Lower Austria that aligns with international policies would clarify their protected or hunting status - but is missing at the moment.

\section{Upper Austria}

The Hunting Act of Upper Austria initially did not list the golden jackal as huntable game. With an amendment in 2012, it was then defined as game in Annex I par. a. The species was previously considered to only occur in other countries; as it now was spotted in Austria, the legislators included the golden jackal in the list of huntable game, enabling the taking of regulatory measures. Simultaneous to the amendment of the hunting act, the Upper Austrian Regulation on hunting periods was adapted. Due to $\S 1$ (1) of the Hunting Regulation of Upper Austria, the golden jackal can be hunted but is protected from 16th March to 30th September. Similar to Burgenland, changing this Regulation would again not require a separate resolution in the provincial parliament; the provincial government could itself change these hunting periods in the future.

\section{Salzburg}

In Salzburg, the golden jackal was already defined as game in the original version of $\S 4$ no. 1 of the hunting act of Salzburg in 1993. Still, similar as in Carinthia, there are no defined hunting periods for the golden jackal. As such, this species is protected all year. In 2002 the golden jackal was then included as well in $\S 72$ (1) no. 2 of the Hunting Act of Salzburg (still, all year protected).

\section{Styria}

Up to the 17 th amendment to the Styrian Hunting Act, the golden jackal was not defined as game. Only since 2014, the golden jackal was inserted in $\S 2$ (1) par. d of the Styrian Hunting Act. The reason for this adaption was considered 'useful', as the golden jackal already occurred sporadically 
in Styria (see preparatory materials relating to the amendment: provincial government bill, October 2014, p. 1, to § 2 (1) and (3)). Only recently, entering into force on 19 December 2020, hunting periods were set (1st October until 15th March), added in $\S 1$ no. 39 of the Styrian Regulation on hunting periods.

\section{Tyrol}

In Tyrol, the golden jackal is neither mentioned in the Hunting Act of Tyrol nor in other hunting-related laws. $§ 5$ (2) of the Nature Conservation Regulation of Tyrol protects species named in Appendix 6 of the Regulation, namely 'all types of non-huntable mammals'. Particularly, (same as in Lower Austria) it is prohibited to deliberately disturb, capture, injure, kill, keep or remove such species, except, for example, for scientific purposes. As the golden jackal is not defined as game in the hunting related laws in Tyrol, the nature conservation provisions are applicable.

\section{Vienna}

The golden jackal is neither mentioned in the Hunting Act of Vienna nor in other hunting-related laws. However, the Regulation on Nature Conservation in Vienna explicitly defines the golden jackal as a strictly protected species in Annex I. For such strictly protected animals, all forms of capturing or killing, regardless of the method used, are prohibited due to the nature conservation of Vienna.

\section{Vorarlberg}

As with Tyrol, the golden jackal is not mentioned in huntingrelated laws in Vorarlberg. Under $\S 6$ (1) of the Nature Conservation Regulation of Vorarlberg, all wild mammals that are not declared huntable game in hunting laws are protected by the Regulation. Due to $\S 5$ (1) of the Nature Conservation Regulation of Vorarlberg, it is prohibited to deliberately disturb, capture, injure, kill, keep or remove such species.

\section{Discussion and Conclusions}

For Austria, the status of the golden jackal must be considered at both national and provincial level. Three international legal instruments set out obligations for the country at a national level: the CBD, the Bern Convention, and the Habitats Directive. The latter clearly indicates that monitoring is obligatory, and sound monitoring is all the more important if a measure like lethal management is declared desirable. As the golden jackal does not have a strict protection status on the basis of the international legislation, the species can in principle be included in hunting laws of the provinces and thus be hunted under the condition that it has a favourable conservation status (FCS) under the Habitats Directive. Nevertheless, to set open hunting seasons, reliable monitoring data have to prove that the FCS has been reached or that the goal of reaching it is not affected by hunting. As mentioned, in Austria practicing hunting and matters of nature conservation are left in the hands of the provinces and therefore no nationwide regulation is applicable. This federal system is, of course, compatible with European law (Article 4 (2) Treaty on the European Union; Article 23d Austrian Constitution, von Bogdandy and Schill 2010). This delegation of authority to the provinces entails specific challenges to ensure a nationwide compliance with European standards; as it is, Austria as an EU member state that remains ultimately responsible for meeting its obligations under the Habitats Directive. If the golden jackal is not declared a game species, the corresponding protective provisions of the provincial nature conservation acts apply automatically. Furthermore, where the species is not declared as game (with or without an open hunting season) under the provincial hunting laws of the provinces, the killing of golden jackals is only possible under the rules of the Austrian Animal Welfare Act.

\section{Hunting and conservation}

Existing legal obligations at international and regional levels restrict Austria and its provinces from completely preventing the colonization by golden jackals. This species is not to be regarded as alien invasive species, and the eradication of pioneering individuals would be at odds with current international law (Trouwborst et al. 2015; European Commission 2016; Somsen and Trouwborst 2019). Nevertheless, the golden jackal can be legally declared as game with an open hunting season as long as the FCS is maintained, or its achievement not hindered. However, to ascertain the conservation status of the population, systematic monitoring measures must be in place. In its absence, according to international regulations, there are three options regarding their status under Austrian provincial legislation: 1) an open hunting period cannot be set, 2) the species must remain protected under the provincial nature conservation laws, or 3 ) the species must be protected year-round in the respective hunting law. This 'year-round-protection' can enable researchers to gather more data on jackal presence in given areas. Possible hunting quotas can be assessed only with this basic knowledge. A main component for the collection of golden jackal records by the provinces that have an open hunting season (e.g. Upper Austria, Burgenland) is a compulsory declaration of animals shot. In provinces without an open hunting season, irrespective of the status within the nature conservation legislation, the collection of records is of utmost importance for future management 
decisions. Provinces should therefore disclose accidentally shot animals.

The use of the term 'Raubzeug' has varied historically and is found in former hunting laws and regulations of Burgenland, Upper Austria, Styria, Tyrol and Vienna. Furthermore, the German Federal Hunting Law used the term until 1976. 'Raubzeug' refers to predator species that might kill or injure game. The term was used not only for stray domestic dogs and cats, but also for native (e.g. rats and crows) and non-native wild species (e.g. raccoon dogs, Nyctereutes procyonoides). The term, however, was never consistently understood among stakeholders (Stinglwagner et al. 2009; Seilmeier and Walz 1983). In Lower Austria, in the case of some corvids, the status changed throughout the years: At first, they were listed as 'Raubzeug', then as protected species and lastly became game within hunting law. To avoid a similar back-and-forth process regarding the legal status of the golden jackal, its inclusion as a game species in provincial law or its inclusion within provincial conservation law would help to clear any uncertainty or discrepancies.

Following the legal interpretation that non-invasive species that are not listed in the hunting law are automatically covered by the Conservation Act of Lower Austria, the golden jackal is protected under nature conservation law in four provinces (i.e. Vorarlberg, Tyrol, Lower Austria, and Vienna). The other five provinces list the golden jackal in their hunting laws. However, only Upper Austria, Burgenland and most recently -Styria have set an open hunting season, meaning, that from 1st October to 15th March it is allowed to hunt the golden jackal, without any minimum or maximum quotas. While in general hunting of golden jackals is permissible under EU law, proof regarding the maintenance of the FCS is required, and pioneering individuals must neither be eradicated nor handled as an invasive species. Two of the provinces that included the golden jackal in their hunting laws are protecting it all yearwhich is currently corresponding to the international and regional obligations.In general, it has to be convincingly shown thatproposed hunting will not prevent the development of the population towards the FCS and the ultimate achievement of such a status (European Commission 2007).

\section{Transboundary efforts and neighbouring countries}

Similar to other species, transboundary management of golden jackals that aligns with respective biogeographical areas and defined populations would presumably be more effective than management that strictly corresponds to political boundaries (Thornton et al. 2018; Trouwborst and Hackländer 2018). Direct neighbours to Austria with persistent presence of golden jackals include Slovenia (Krofel 2009; Krofel et al. 2017), Italy (Fanin et al. 2018; Lapini et al. 2018), and Hungary (Szabó et al. 2009). In the Czech Republic first sightings were documented in Koubek and Cerveny (2007), and first reproduction was confirmed in 2017 (Jirků et al. 2018). In Poland, reproduction was only confirmed in 2019 (Kowalczyk et al. 2020), and in the same year, territorial golden jackal groups were confirmed in Slovakia by means of bioacoustic monitoring (Guimarães et al. 2019a, b). In the remaining neighbouring countries - Switzerland (first record 2012), Liechtenstein (first record 2018), and Germany (first record 1998) - no reproducing golden jackals have been confirmed to date.

As the golden jackal distribution is obviously in a very dynamic process (Lapini et al. 2018) - what is the legal status in Central European countries with relatively new occurrence or longer known presence and what are the latest adaptations? In Austria, in 2007, the golden jackal had a nationwide protected status and was only listed as a game species (all year protected) in the province of Salzburg. Plass (2007) therefore considered Austria as acting responsibly compared to other countries. Likewise, Rutkowski et al. (2015) argued that the golden jackal should be treated as a protected species in newly colonized countries and, given the difficulties to collect hard data on the species presence, a careful assessment of this new situation is needed. In Germany, the golden jackal is not listed in the federal hunting law and therefore automatically protected (Hatlauf and Hackländer 2018). In Poland, the golden jackal was listed as a game species only in 2019 and given an open season from 1st August to end of February (Minister Środowiska 2017), with a maximum quota of 1270 individuals set for the hunting period of 2019/20 (Jurszo 2019). In the Czech Republic, the species has no legal status, and it is not listed in the hunting act (Trouwborst et al. 2015), indicating that killing is not forbidden but can be permitted by the nature conservation authority (M.Šálek, personal comment). In Slovakia, the golden jackal has been listed as game since 2013, with an open hunting season from 1st of August to end of February (Ministerstva pôdohospodárstva a rozvoja vidieka Slovenskej republiky 2013). In Hungary, jackals can be hunted as game year-round (FVM rendelet a vad védelméről, a vadgazdálkodásról, valamint a vadászatról szóló 1996). In Slovenia, the legal status changed back and forth, from protected to game species, again to protected (with active monitoring efforts) and finally to game with an open season and a set quota, starting in 2020 (Mladenovič et al. 2015; Potočnyk et al. 2019). In contrast, Italy lists the golden jackal as a specially protected species (Gazetta Ufficiale della republica Italiana 1992); and Lapini et al. (2011) urged for the adoption of a conservation plan. In Switzerland, the species is protected implicitly because it is not listed in the federal hunting law (Bundesgesetz über die Jagd und den Schutz wildlebender Säugetiere und Vögel 2017; Hatlauf et al. 2018b) and is therefore a protected species as well. In the principality of Liechtenstein, the golden jackal has been a protected species since 2017, even before the first individual 


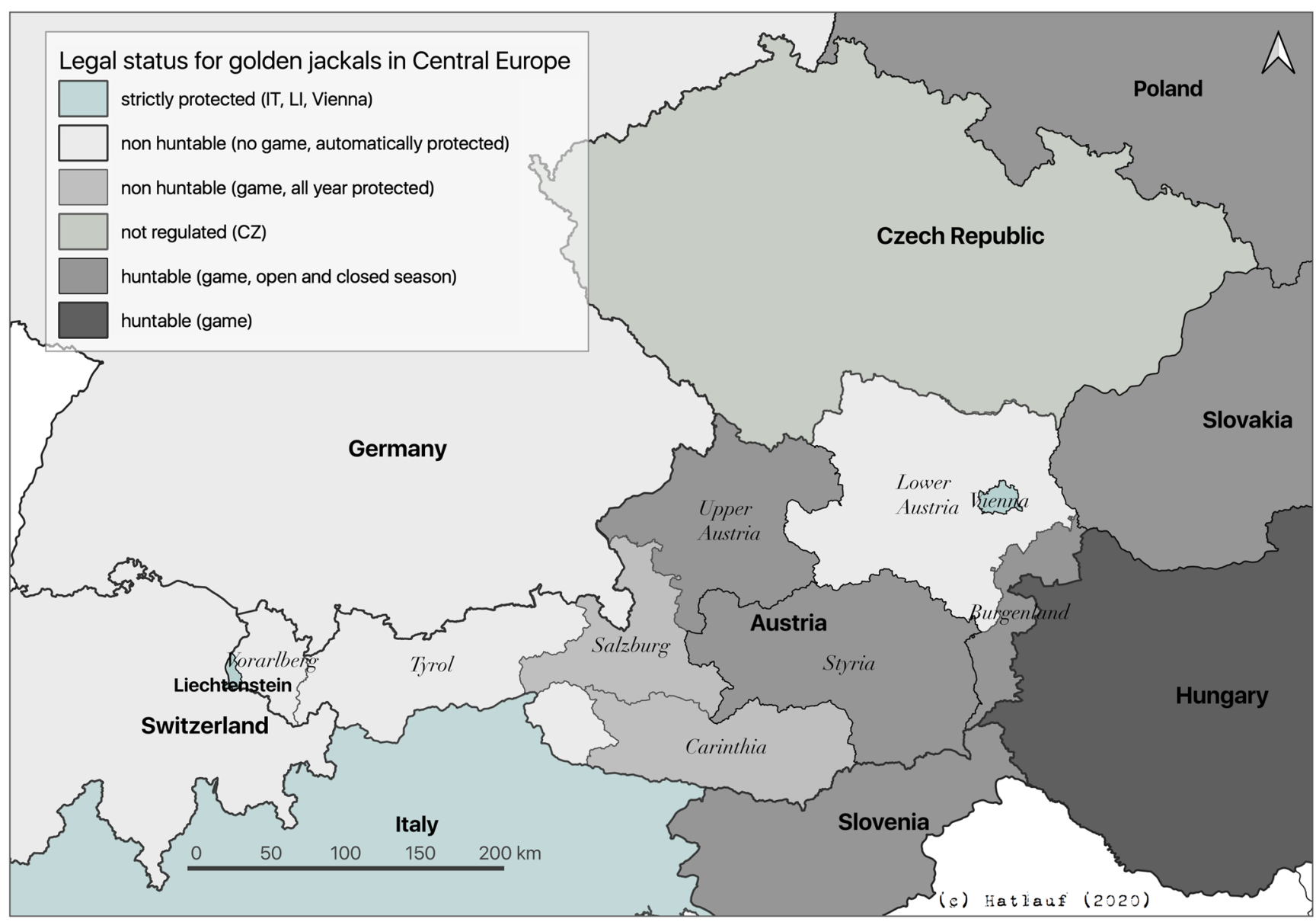

Fig. 2 Simplified visualization of the legal status of the golden jackal in Central European countries (for Austrian provinces, see details in Fig. 1): 'strictly protected' = light blue-grey in IT, Vienna, LI; 'non huntable' = light grey, meaning, that it is not listed within hunting law (no game) and therefore automatically protected (Lower Austria, DE, CH); 'non huntable' = mid grey, listed within the hunting law (game) but all year protected (Carinthia, Salzburg); 'not regulated' = mid green-grey, indicating that killing is not forbidden but needs permission by the nature conservation authority (CZ); 'huntable (game, open, and closed season)' = darker/mid grey (SI, SK, Burgenland, Upper Austria, Styria); 'huntable $(\text { game })^{\prime}=$ dark grey, indicating that there is an open season all year $(\mathrm{HU})$ (Status 2020) was confirmed (Liechtensteinisches Landesgesetzblatt 2017) (summarized visualization in Fig. 2).

This overview of the legal regulations shows that not only in our country of focus, Austria, but also in other countries on a transnational level, the differences can be diametrical. As Pyšková et al. (2016) pointed out, opinions (and also thereafter legal implications) about this species' status in Europe will likely also differ between regions or countries in the future, and with good reasons. This leads us to the following reflections:

An important consideration regarding the golden jackal is the level of systematic assessment and the scale, or scales, at which the FCS should be looked at, as discussed above. FCS is most likely not yet reached within any single province of Austria. By contrast, when setting the scale on the broadest transboundary level, the estimated European-scale population of 97-117 K individuals (LCIE 2018) might indicate the FCS has been reached, but only at this broad continental scale. However, as shown above, neither the provincial nor the continental level would appear to provide adequate benchmarks in the context of Austria's obligations under the Habitats Directive. The previously mentioned recent EU court ruling (Case C-674/17, 10 October 2019) on the possible levels of populations might provide a starting point, but more comprehensive guidelines are needed. The aforementioned continental population estimate is possibly an underestimate, as it might exclude freshly settled groups (even though these numbers might not be remarkably high). The basis for an assessment of the FCS in 'newly colonized' areas might include estimates of population size and trend within but also beyond country borders that are based on chance records in addition to systematic monitoring. The quality of data must be carefully considered when generating these estimates and quality criteria are needed. Solely relying on chance observations like roadkill would lead to an overestimation of the settled distribution area by most likely recording only vagrant individuals. On the other hand, relying solely on bioacoustic stimulation in areas of recently settled golden jackals, of low 
density with most likely low detection rate (unpublished data) could lead to an underestimation of the true distribution due to false absences: non-detection does not necessarily imply absence; even more so in the case of the very secretive golden jackal.

\section{Consensus, cooperation, and future topics}

Regarding our initial questions from the introduction, lethal control of golden jackals can be in accordance with international legislation as long as it does not interfere with the achievement or maintenance of a FCS, and applicable methods are in conformity with those rules. If hunting periods are desired, open seasons should be applied in consideration of the reproductive biology of the species, at a time period, when the young are already independent. As damage to livestock by golden jackals was previously recorded (Fanin et al. 2018), possible compensations should be discussed (Linnell et al. 2008). Although there are indications that compensation does not necessarily improve tolerance with some stakeholders, it might still result in better acceptance among affected farmers (Rigg et al. 2011). Furthermore, monitoring of golden jackals is necessary to regularly assess the conservation status and, moreover, to help promote human-predator coexistence in combination with clear management and legal regulations. Opinions, attitudes, interpretations and misinformation can influence policy-making related to wildlife. For example, in Lithuania, the golden jackal was initially listed as an alien species, although the animals were expanding naturally and did not appear because of introductions by humans (Trouwborst et al. 2015; Rutkowski et al. 2015; European Commission 2016). Besides the assessment of the spread and occurrence of golden jackals in Europe, examining behavioural ecology, feeding behaviour, diet, empirical levels of predation, and ecosystem services need to be investigated thoroughly and included in the discussions about the species.

To find consensus and cooperation for an integrated management between hunting, conservation and science, new rules (e.g. integration of agreed legal tools, support in the decision process, common methodology in monitoring and assessment, and open discussions) need to replace old concepts or entrenched practices. Different cultural models might also be relevant for further consideration of communicating species management (Maran 2015). In 2016, a hunter shot a golden jackal in Switzerland (where it is protected countrywide) by accident, expecting it to be a red fox, and he immediately reported this mistake to the authorities (Amt für Jagd und Fischerei Graubünden 2016). This kind of voluntary declaration of accidentally shot golden jackals would greatly benefit Austria's provinces in the determination of a FCS. It would furthermore not only contribute to long-term monitoring, but also inform ongoing decision-making about the legal status for golden jackals in the provinces. No matter the consequence, we urge for truthful cooperation and transparency rather than secrecy in hunting practices or species conservation. Furthermore, we recommend that the provincial status of the golden jackal should be revisited with regard to international law and in alignment to the species' ecology, conservation status and experiences in other European countries (e.g. a countrywide monitoring to assess the population was carried out in Slovenia). Because of assumed preferred habitats and previous models (Hatlauf et al. 2016a), monitoring areas for Austria might have to be adapted to the already existing European reporting requirements under Article 17 of the EU Habitats Directive, in this case, specifying an assessment divided into alpine and continental region. Based on our findings we suggest an evaluation of the status of golden jackals in each of Austria's provinces with continuous monitoring of the development of the population in Europe.

Acknowledgements Open Access funding provided by University of Natural Resources and Life Sciences Vienna (BOKU). J.H. is a recipient of the DOC Fellowship of the Austrian Academy of Sciences at the Institute of Wildlife Biology and Game management. A.T. was funded by the Netherlands Organization for Scientific Research, under the Ius Carnivoris project (grant no. 452-13-014). We would like to express our gratitude to colleagues who provided information from certain countries-Hubert Potočnik, Yannik Fanin, Nuno Guimarães, and Martin Š́lek. We furthermore thank our colleagues Brady Mattsson, Robin Sandfort, Marcela Suarez-Rubio, Miklós Heltai, and Laurent Schley for valuable comments regarding the topic or the manuscript.

\section{Compliance with ethical standards}

Conflict of interest The authors declare that they have no conflict of interest.

Open Access This article is licensed under a Creative Commons Attribution 4.0 International License, which permits use, sharing, adaptation, distribution and reproduction in any medium or format, as long as you give appropriate credit to the original author(s) and the source, provide a link to the Creative Commons licence, and indicate if changes were made. The images or other third party material in this article are included in the article's Creative Commons licence, unless indicated otherwise in a credit line to the material. If material is not included in the article's Creative Commons licence and your intended use is not permitted by statutory regulation or exceeds the permitted use, you will need to obtain permission directly from the copyright holder. To view a copy of this licence, visit http://creativecommons.org/licenses/by/4.0/.

\section{References}

Amt für Jagd und Fischerei Graubünden (2016) Goldschakal in Graubünden. Kanton Graubünden. https://www.gr.ch/DE/Medien/ Mitteilungen/MMStaka/2016/Seiten/2016011302.aspx. Accessed 30 Sept 2020

Anonymous (2017) Goldschakal tötete Lämmer in Nordschleswig. Der Nordschleswiger. https://www.nordschleswiger.dk/de/ nordschleswig/goldschakal-toetete-laemmer-nordschleswig. Accessed 30 Sept 2020 
Anonymous (s.a) Jagdschutz. In: NÖ Jagdrecht http://docplayer.org/ 73466848-Noe-jagdrecht-1-fusszeile.html. p 229. Accessed 30 Sept 2020

Arnold J, Humer A, Heltai M, Murariu D, Spassov N, Hackländer K (2012) Current status and distribution of golden jackals Canis aureus in Europe. Mammal Rev 42:1-11

Bauer K, Suchentrunk F (1995) Further distribution of the golden jackal Canis aureus L., 1758 in Austria. Z Säugetierkd 60:307-309

Bouchet ST (2017) Le chacal doré observé pour la première fois en France. Le dauphiné. https:/www.ledauphine.com/insolite/2017/ 12/14/le-chacal-dore-observe-pour-la-premiere-fois-en-france. Accessed 30 Sept 2020

Bowman M, Redgwell C, Davies P (2010) Lyster's international wildlife law, 2nd. Cambridge University Press, Cambridge

Bundesgesetz über die Jagd und den Schutz wildlebender Säugetiere und Vögel (Jagdgesetz, JSG) (2017) https://www.admin.ch/opc/de/ classified-compilation/19860156/201705010000/922.0.pdf. Accessed 30 Sept 2020

CBD (1992) Convention on Biological Diversity of 5 June 1992 https:// www.cbd.int/doc/legal/cbd-en.pdf. Accessed 30 Sept 2020

Ćirović D, Penezić A, Milenković M, Paunović M (2014) Winter diet composition of the golden jackal (Canis aureus L., 1758) in Serbia. Mamm Biol 79(2):132-137

CITES (1973) The Convention on International Trade in Endangered Species of Wild Fauna and Flora of 3 March 1973 https://www. cites.org/eng/disc/text.php. Accessed 30 Sept 2020

CMS (1979) The Bonn Convention on the Conservation of Migratory Species of Wild Animals of 23 June 1979, https://www.cms.int/ sites/default/files/instrument/CMS-text.en .PDF. Accessed 30 Sept 2020

Dios C, Ulicsni V, Molnar Z (2018) The background of human-wildlife conflicts in connection with the golden jackal. In: Giannatos G, Banea OC, Hatlauf J, Sillero-Zubiri C, Georgiadis C, Legakis A (eds) Proceedings of the 2nd International Jackal Symposium, Marathon Bay, Attiki Greece. Hell. Zool. Arch. No. 9, p 98

Epstein Y, Lopez-Bao JV, Chapron G (2016) A legal-ecological understanding of favorable conservation status for species in Europe. Conserv Lett 9:81-88

EU Habitats Directive (1992) the Council Directive 92/43/EEC of 21 May 1992 on the conservation of natural habitats and of wild fauna and flora, https://eur-lex.europa.eu/legal-content/EN/TXT/PDF/? uri=CELEX:31992L0043\&from=EN. Accessed 30 Sept 2020

European Commission (2007) Guidance document on the strict protection of animal species of Community interest under the Habitats Directive 92/43/EEC. European Commission, Brussels

European Commission (2016) Golden jackal should not be treated as an alien species in Europe. Sci Environ Policy 443:1-2

European Union (2017) Invasive Alien Species of Union concern, https:// ec.europa.eu/environment/nature/pdf/IAS_brochure_species.pdf. Accessed 30 Sept 2020

Evans D, Demeter A, Gajdo P, Halada L (2013) Adapting environmental conservation legislation for an enlarged European Union: Experience from the Habitats Directive. Environ Conserv 40(2): 97-107

Fanin Y, Pesaro St, Filacorda St, Pieri M (2018) Golden jackal (Canis aureus moreoticus Geoffroy, 1835) predatory behaviour and carcass consumption of livestock in North East Italy. In: Giannatos G, Banea OC, Hatlauf J, Sillero-Zubiri C, Georgiadis C, Legakis A (eds) Proceedings of the 2nd International Jackal Symposium, Marathon Bay, Attiki Greece. Hell. Zool. Arch. No. 9, p 93

Farkas A, Jánoska F, Fodor J-T, Náhlik A (2017) The high level of nutritional niche overlap between red fox (Vulpes vulpes) and sympatric golden jackal (Canis aureus) affects the body weight of juvenile foxes. Eur J Wildl Res 63(3):46

FVM rendelet a vad védelméröl, a vadgazdálkodásról, valamint a vadászatról szóló (1996) 79/2004. (V. 4.). Nemzeti Jogszabálytár. http://njt.hu/cgi_bin/njt_doc.cgi?docid=85128.365826\#foot3. Accessed 30 Sept 2020

Gazetta Ufficiale della republica Italiana (1992) Art 2 Legge 11 febbraio 1992, n. 157, GU Serie Generale n. 46 del 25-02-1992 Supplemento Ordinario n. $41 \mathrm{https}$ ://www.gazzettaufficiale.it/eli/ $\mathrm{gu} / 1992 / 02 / 25 / 46 / \mathrm{so} / 41 / \mathrm{sg} / \mathrm{pdf}$. Accessed 30 Sept 2020

Graham KJ, Beckerman AP, Thirgood SJ (2005) Human-predator-prey conflicts: ecological correlates, prey losses and patterns of management. Biol Conserv 122:159-171

Guimarães N, Wirk L, Urban P, Hatlauf J (2019a) Searching for shy canid species - Wolf (Canis lupus) and golden jackal (Canis aureus) records in potential co-existence areas of Austria and Slovakia. In: Bryja J, Horsák M, Horsáková V, Zukal J (eds) Book of abstracts, Zoologické dny, konference, 7.-8.02.2019. Brno, Czech Republic 2019, pp. 63-64

Guimarães N, Bučko J, Urban P (2019b) The rise of a carnivore, the evolution of the presence of the golden jackal in Slovakia. Folia Zool 68(2):66-71

Harrop, (2011) Climate change, conservation and the place for wild animal welfare in international law. J Environ Law 23(3):441-462

Hatlauf J, Hackländer K (2016a) Preliminary results for golden jackal (Canis aureus) survey in Austria. Beitr Jagd Wildforsch 41:295-306

Hatlauf J, Hackländer K (2016b) Current status of a spreading mesocarnivore in Austria, the golden jackal (Canis aureus). Mamm Biol 81(Suppl):8

Hatlauf J, Hackländer K (2018) Besuch aus dem Balkan - der Goldschakal in Deutschland. Wild und Hund 6(2018):16-22

Hatlauf J, Suppan F, Hackländer K (2016a) Der Goldschakal (Canis aureus, L.1758) - Status, Habitatfaktoren und Modellierungsansatz. Säugetierkd Inform 50:133-153

Hatlauf J, Banea O C, Lapini L (2016b) Assessment of golden jackal species (Canis aureus, L.1758) records in natural areas out of their known historic range. Technical Report: GOJAGE Criteria and Guidelines, eBulletin 12.02.2016

Hatlauf J, Heltai M, Szabó L, Hackländer K (2017) Golden jackal (Canis aureus) occurrence in Austria: from first records to recent findings. In: Bro E, Guillemain $\mathrm{M}$ (eds) $33^{\text {rd }}$ International Union of Game Biologists Congress, IUGB, Montpellier 2017, p 178

Hatlauf J, Heltai M, Duscher T (2018a) Der Goldschakal - Daten und Fakten. Info-Blatt des Burgenländischen Jagdverbandes 1/2018:8-14

Hatlauf J, Zimmermann F, Kunz F, Hackländer K (2018b) Goldschakale in Europa und in der Schweiz. Schweizer Jäger 9/2018:56-62

Head BW (2016) Toward more 'evidence-informed' policy making? Public Adm Rev 76:472-484

Heltai M, Ćirovi D, Szabó L, Penezi A, Nagyapáti N, Kurys A, Lanszki J. (2013) Golden jackal: opinions versus facts - Experiences from Serbia and Hungary. In: Beuković M, Popović Z, Đorđević N, Đan M, Beuković D, Lavadinović V (eds) Proceedings of the 2nd International Symposium on Hunting: Modern Aspects of Sustainable Management of Game Populations. Novi Sad, Serbia 2013, pp. 13-20

Herzig-Straschil B (2008) Short note: First breeding record of the golden jackal (Canis aureus L., 1758, Canidae) in Austria. Ann Nat Hist Mus Wien. Ser B Bot Zool 109:73-76

Hessenberger M (2017) Schakale bedrohen Wild in der Steiermark. Salzburger Nachrichten. https://www.sn.at/panorama/oesterreich/ schakale-bedrohen-wild-in-der-steiermark-21596467. Accessed 30 Sept 2020

Hoi-Leitner M, Kraus E (1989) Golden jackal, Canis aureus (Linnaeus, 1758), in Austria (Mammalia Austriaca 17). Bonn Zool Beitr 40(3/4):97-204

Humer A (2006) Goldschakale in Österreich. Aktueller Status und Managementstrategien unter besonderer Berücksichtigung der Einstellung und des Wissens zum Thema Goldschakal bei österreichischen Bezirksjägern. Master Thesis, University of Natural Resources and Life Sciences, Vienna 
IAS Regulation (EU) (2014) No 1143/2014 of the European Parliament and of the Council of 22 October 2014 on the prevention and management of the introduction and spread of invasive alien species, https://eur-lex.europa.eu/legal-content/EN/TXT/PDF/?uri=CELEX: 32014R1143\&from=EN. Accessed 30 Sept 2020

Jirků M, Dostál D, Robovský J, Šálek M (2018) Reproduction of the golden jackal (Canis aureus) outside current resident breeding populations in Europe: evidence from the Czech Republic. Mammalia 82(6):592-595

Jurszo R (2019) 1270 szakali do odstrzału w Polsce. Naukowcy: „Będą mylone z wilkami”. Ale może właśnie o to chodzi. https://oko.press/ 1270-szakali-do-odstrzalu-w-polsce-naukowcy-beda-mylone-zwilkami-ale-moze-wlasnie-o-to-chodzi. Accessed 30 Sept 2020

Koistinen A (2019) Tutkija vahvistaa: Suomen ensimmäinen sakaalihavainto Rautavaaralla - yksilö on todennäköisesti sama, joka oli Enossa - kuvat. Karjalainen. https://www.karjalainen.fi/ uutiset/uutis-alueet/kotimaa/item/224551. Accessed 30 Sept 2020

KORA (2012) Erster Goldschakal-Nachweis in der Schweiz. KORA News. http://www.kora.ch/index.php?id=214andL=1 andtx_ttnews\%5Btt news\%5D=408andcHash=be9f32a37b98a1803257ca8cba134 657. Accessed 30 Sept 2020

Koubek P, Cerveny J (2007) The golden jackal (Canis aureus) - a new mammal species in the Czech Republic. Lynx (Praha) 38:103-106

Kowalczyk R, Kołodziej-Sobocińska M, Ruczyńska I, Wójcik JM (2015) Range expansion of the golden jackal (Canis aureus) into Poland: first records. Mammal Res 60(4):411-414

Kowalczyk R, Wudarczyk M, Wójcik JM, Okarma H (2020) Northernmost record of reproduction of the expanding golden jackal population. Mamm Biol 100(1):107-111

Krofel M (2009) Confirmed presence of territorial groups of golden jackals (Canis aureus) in Slovenia. Nat Slov 11:65-68

Krofel M, Giannatos G, Ćirović D, Stoyanov S, Newsome TM (2017) Golden jackal expansion in Europe: a case of mesopredator release triggered by continent-wide wolf persecution? Hystrix 28(1):9-15

Landesverwaltung Fürstentum Liechtenstein (2018) Erstnachweis in Liechtenstein: Goldschakal tappt in Fotofalle. https://www.llv.li/ medienmitteilungen/detail/2430. Accessed 30 Sept 2020

Lanszki J, Kurys A, Szabó L, Nagyapáti N, Porter LB, Heltai M (2016) Diet composition of the golden jackal and the sympatric red fox in an agricultural area (Hungary). Folia Zool 65(4):310-322

Lapini L, Conte D, Zupan M, Kozlan L (2011) Italian golden jackals 1984-2011: an updated review. Boll Museo Civico Storia Nat Venezia 62:1-20

Lapini L, Dreon AL, Caldana M, Luca M, Villa M (2018) Distribuzione, espansione e problemi di conservazione di Canis aureus in Italia (Carnivora: Canidae). Quaderni Museo Civico Storia Nat Ferrara 6/2018:89-96

LCIE (2018) Golden jackal - Canis aureus. Large Carnivore Initiative for Europe. https://www.lcie.org/Large-carnivores/Golden-jackal. Accessed 30 Sept 2020

Lebersorger P (2009) Rechtliche Situation von Beutegreifern in Österreich, Vortrag. WWF. https://www.wwf.at/de/view/files/ download $/$ showDownload/?tool=12\&feld=download \&sprach connect $=1211$. Accessed 30 Sept 2020

Levickaite R (2015) Lietuvoje sumedžiotas pirmasis šakalas - didžiulès bėdos pranašas (engl: First Golden jackal Hunted in Lithuania, Prophecy of Big Trouble Ahead). Grynas-Delfi. http://grynas.delfi. 1t/gamta/lietuvoje-sumedziotas-pirmasis-sakalas-didziules-bedospranasas.d $\mathrm{id}=67703144 \#$ \#xzz3aPZt6g49. Accessed 30 Sept 2020

Liechtensteinisches Landesgesetzblatt 144 (2017) Verordnung vom 19. Dezember 2017 über spezifisch geschützte Pflanzen- und Tierarten. https://www.gesetze.li/konso/pdf/2017444000?version=1. Accessed 30 Sept 2020

Linnell J, Salvatori V, Boitani L (2008) Guidelines for population level management plans for large carnivores. A Large Carnivore Initiative for Europe report prepared for the European Commission, Rome
Männil P, Jogisalu I, Ozolins J, Maran T (2014) Golden jackal - new carnivore species in Northern Europe? 9th Baltic Theriological Conference, Book of Abstracts. Daugavpils, Latvia 2014, p 47

Maran T (2015) Emergence of the 'Howling Foxes': A Semiotic Analysis of Initial Interpretations of the Golden jackal (Canis aureus) in Estonia. Department of Semiotics. Univ Tartu Biosemiotics 8(3):463-482

Minister Środowiska (2017) Klub Przyrodników, 31 July 2017. https:// www.kp.org.pl/pdf/stanowiska/inne/2017-07-31_KP\% 20stanowisko\%20ws\%204\%20rozporzadzen\%20lowieckich.pdf. Accessed 30 Sept 2020

Ministerium für Energiewende, Landwirtschaft, Umwelt, Natur und Digitalisierung (2017) Erster Goldschakal in Schleswig-Holstein nachgewiesen. SHZ. https://www.shz.de/16890251. Accessed 30 Sept 2020

Ministerstva pôdohospodárstva a rozvoja vidieka Slovenskej republiky (2013) hunting act No. 274/2009 with Amendment No. 489/2013 https://www.noveaspi.sk/products/lawText/1/92880/1/2?vtextu= sakal\&timeslice $=$ null\#lema0. Accessed 30 Sept 2020

Mladenovič J, Krofel M, Berce T, Deržič M, Tarman J (2015) Zlati šakal nova lovna vrsta v Sloveniji. Svet ptic, letnik 21, številka 1, p 14-15

Molinari-Jobin A, Molinari P, Breitenmoser-Wuersten C, Woelfl M, Stanisa C, Fasel M, Stahl P, Vandel JM, Rotelli L, Kaczensky P, Huber T, Adamic M, Koren I, Breitenmoser U (2003) The panAlpine conservation strategy for the lynx. Nat Environ 130:1-19

Paulauskas A, Ražanskė I, Radzijevskaja J, Nugaraite D, Gedminas V (2018) The golden jackal Canis aureus - a new species in the Baltic countries. Biologija 64(3):203-207

Plass J (2007) Dokumentation einer zweiten Einwanderungswelle des Goldschakals Canis aureus Linnaeus, 1758 in Österreich aus den Jahren 2003-2006. Beiträge Naturkunde Oberösterreichs 17:55-68

Potočnyk H, Pokorny B, Flajsman K, Kos I (2019) Evrazijski Šakal. Lovska zveza Slovenije, Ljubljana

Pyšková K, Storch D, Horáček I, Kauzál O, Pyšek P, (2016) Golden jackal (Canis aureus) in the Czech Republic: the first record of a live animal and its long-term persistence in the colonized habitat. ZooKeys 641(December):151-163. https://doi.org/10.3897/ zookeys.641.10946

Rigg R, Findo S, Wechselberger M, Gorman M, Sillero-Zubiri C, Macdonald D (2011) Mitigating carnivore-livestock conflict in Europe: Lessons from Slovakia. Oryx 45(2):272-280

Rutkowski R, Krofel M, Giannatos G, Ćirović D, Mannil P, Volokh AM, Bogdanowicz W (2015) A European concern? Genetic structure and expansion of golden jackals (Canis aureus) in Europe and the Caucasus. PLoSOne 10(11):e0141236

Seilmeier G, Walz K L (1983) Jagdlexikon. BLV, München

Sinclair ARE, Fryxell JM, Caughley G (2012) Wildlife ecology, conservation, and management. 2nd. Blackwell Publishing Ltd., Oxford

Somsen H, Trouwborst A (2019) Are pioneering coyotes, foxes and jackals alien species? Canid colonists in the changing conservation landscape of the Anthropocene. Oryx 54(3):392-394

Spassov N (1989) The position of jackals in the Canis genus and lifehistory of the golden jackal (Canis aureus L.) in Bulgaria and on the Balkans. Hist Nat Bulg 1:44-56

Spassov N, Acosta-Pankov I (2019) Dispersal history of the golden jackal (Canis aureus moreoticus Geoffroy, 1835) in Europe and possible causes of its recent population explosion. Biodiv Data J 7:e34825

Stinglwagner R, Haseder G, Erlbeck I (2009) Das Kosmos Wald- und Forstlexikon, 4th edition, Erlbeck R (Ed.): Das Kosmos-Wald- und Forstlexikon. Kosmos, Stuttgart

Stratford J (2015) Golden jackal in Lithuania, a consideration of its arrival, impact and status. Zool Ecol 25(4):277-287

Szabó L, Heltai M, Szücs E, Lanszki J, Lehoczki R (2009) Expansion range of the golden jackal in Hungary between 1997 and 2006. Mammalia 73(4):307-311

The Bern Convention on the Conservation of European Wildlife and Natural Habitats (1979) 19 October 1979, https://www.coe.int/en/ 
web/conventions/full-list/-/conventions/rms/0900001680078aff. Accessed 30 Sept 2020

Thöne S (2012) Jäger erlegt einen Goldschakal, https://www.meinbezirk. at/enns/c-lokales/jaeger-erlegt-einen-goldschakal_a358579. Accessed 30 Sept 2020

Thornton DH, Wirsing AJ, Lopez-Gonzalez C, Squires JR, Fisher S, Larsen KW, Peatt A, Scrafford MA, Moen RA, Scully AE, King TW, Murray DL (2018) Asymmetric cross-border protection of peripheral transboundary species. Conserv Lett 11(3):e12430

Tóth T, Krecsák L, Szücs E, Heltai M, Huszár G (2009) Records of the golden jackal (Canis aureus Linnaeus, 1758) in Hungary from 1800th until 2007, based on a literature survey. North-West J Zool $5(2): 386-405$

Trolle M (2015) Guldsjakaler i Danmark. Ulve i Denmark. https:// ulveidanmark.ku.dk/guldsjakal/guldsjakaler-i-danmark. Accessed 30 Sept 2020

Trouwborst A, Hackländer K (2018) Wildlife Policy and Law in Europe. In: Leopold B, Kessler WB, Cummins JL (eds) North American Wildlife Policy and Law, Boone and Crockett Club, pp. 425-443

Trouwborst A, Krofel M, Linnell JDC (2015) Legal implications of range expansions in a terrestrial carnivore: the case of the golden jackal (Canis aureus) in Europe. Biodivers Conserv 24(10):2593-2610

Trouwborst A, Fleurke FM, Linnell JDC (2017a) Norway's Wolf Policy and the Bern Convention on European Wildlife: Avoiding the 'Manifestly Absurd'. J Internat Wildl Law Policy 20(2):155-167
Trouwborst A, Boitani L, Linnell JDC (2017b) Interpreting favourable conservation status for large carnivores in Europe: how many are needed and how many are wanted? Biodivers Conserv 26(1):37-61

van der Grift E.A (2016) First golden jackal spotted in the Netherlands. Alterra News, Wageningen University\& Research. https://www. wur.nl/en/newsarticle/First-golden-jackal-spotted-in-theNetherlands.htm. Accessed 30 Sept 2020

Veeroja R, Männil P (2018) Ulukiasurkondade seisund ja Küttimissoovitus 2018 - Status of Game populations in Estonia and proposal for hunting in 2018, Estonian Environment Agency, Tartu, pp. 84-87

von Bogdandy A, Schill S (2010) Die Achtung der nationalen Identität unter dem reformierten Unionsvertrag. Zur unionsrechtlichen Rolle nationalen Verfassungsrechts und zur Überwindung des absoluten Vorrangs. ZaöRV - HJIL 70:701-734

Wallendums P (2019) Angyali ördögök? Magyar Vadászlap 02(2019): 18-19

Zedrosser A (1995) Eine neue Tierart für Österreich: Der Goldschakal (Canis aureus). Stapfia 37:237-242

Publisher's note Springer Nature remains neutral with regard to jurisdictional claims in published maps and institutional affiliations. 